\title{
The Hedonic Approach to Vineyard Site Selection: Adaptation to Climate Change and Grape Growing in Emerging Markets*
}

\author{
Orley Ashenfelter ${ }^{a}$
}

\begin{abstract}
This paper shows how the hedonic approach to vineyard site selection can be used in the adaptation of vineyard land to climate change, natural disasters or other exogenous events. The basic idea is that, if the relation between weather and grape quality is known for each grape type in existing growing areas, then it is possible to predict the quality of grapes that would be produced in other locations, or in the same location with a changed climate. This permits the optimization of grape type selection for a location and also provides an indication of the value that a particular planting should produce. The relation of grape quality to the weather is provided for several well-known viticultural areas, including Burgundy, Bordeaux, Rioja, and the Piedmont. An application of the method to a new vineyard area in the Czech Republic following the demise of Communism is used to demonstrate the method. (JEL Classifications: O21, Q16, Q18, Q54)
\end{abstract}

Keywords: Vineyard Site, Hedonic Method, Grape Growing, Climate Change.

\section{Introduction}

This paper contains an empirical analysis of the use of the hedonic method to optimize the selection of vineyard sites for growing high quality red wine grapes. The basic idea of this approach is first to measure empirically the relation between wine quality and its determinants for each grape type. With this empirical

\footnotetext{
* This is an updated and extended version of a presentation prepared for the Fifth Annual Meeting of the Vineyard Data Quantification Society, October 3-4, 1997, University of Macedonia, Thessaloniki, Greece. The author is especially indebted to Giuseppe Gaburro, Victor Ginsburgh, and to Andreas and Nico Papandreou for helpful discussions and assistance. The results for the application of the hedonic method to the Moravian region resulted from a visit to the Czech Republic, and I am indebted to Jan Svejnar, Randy Filer, and the students at the Center for Graduate Education/Economics Institute of the Charles University in Prague for their guidance and field work.

${ }^{a}$ Economics Department, Industrial Relations Section, Firestone Library, Princeton University, Princeton, NJ 08544-2098; e-mail: c6789@princeton.edu.
} 
relationship in hand it should then be possible to select the optimizing grape type for each location, estimate the quality of wines that can be produced in a particular area, and judge whether wine grape production is economically viable.

The value of the hedonic method is that it provides important information for key decisions about how to optimize wine grape quality and thus the value of wine production. Climate change has made these issues especially pressing in the major grape growing and wine producing countries. The hedonic approach provides a guide to the adaptation that may be necessary if temperatures continue to increase in established grape growing regions.

Equally important is the growth and increased reliance on the market place for adding value to the economies of the former Soviet bloc countries, South America, South Africa, and China. Optimizing the value of wine production in these emerging areas is an important topic for both public and private decision making. In addition, as incomes grow throughout the world, so does the demand for higher quality wine. The plantation of older vineyard areas may, therefore, require adaptation to crops of higher quality in order to maintain their economic viability.

The production of wine is much like the production of any food product. The three key ingredients are (a) a recipe (winemaking technique), (b) a reliable method for implementing the recipe (a winemaker and equipment), and (c) raw ingredients (grapes). In principle, it would be possible to apply the hedonic method to each component of the winemaking process. The focus of this paper, however, is the role of grape quality in the production of red wines. This does not mean that the role of winemaking technique is small, only that it should be subject of a separate study. In what follows it is assumed that, given the fruit available, the best recipe is selected and implemented. It follows that the only remaining determinant of the quality of the final product is the quality of the fruit used in the product.

The key to using the hedonic approach to vineyard and grape selection is to establish empirically the relationship between the characteristics of the vineyard and the quality of the resulting wine produced from the grapes from that vineyard. Once this relationship is known for each grape type it is possible to predict the quality of wine that can be produced from any candidate site using a particular grape type. In principle this procedure could be used to predict the quality level for each candidate vineyard site for each grape type. The optimal grape type could then be selected for any vineyard site, and the likely quality, and thus the price or economic value of the resulting wine, could also be predicted. ${ }^{1}$ Naturally, given the vineyard site, some grape types may be more suitable than others. Likewise, given the grape type, some sites may be expected to produce higher quality grapes than others.

\footnotetext{
${ }^{1}$ Issues besides wine quality also determine the economic viability of grape farming. These include the determinants of grape quantity (or crop yield, which is typically determined in the spring before the growing season) and the possibility of vine destruction in harsh winter weather. A vine typically does not produce a full crop until its fourth leaf, which means that winter damage has a heavy capital cost.
} 
In the last two decades several researchers have begun to quantify the relationship between year to year fluctuations in wine quality and year to year fluctuations in the weather in selected vineyard areas. ${ }^{2}$ This research provides precisely the empirical foundation for the hedonic approach. The first part of this paper provides a review of the results that are available from vineyard sites in France, Australia, Italy, the Czech Republic, and Greece. Much of this research is still in a preliminary form and much is unpublished. A primary problem that has been encountered by many authors is the virtual impossibility of finding objective measures of the average quality of the wines of a vintage to use for the purposes of estimation. One purpose of this review is to show how subjective measures of wine quality may be used to calibrate the role of weather in the determination of wine quality. The other is to summarize what seems thus far to have been established about the role of weather in determining vintage quality.

The second part of the paper consists of an illustrative application of the hedonic approach to determining wine quality in a region where a particular grape type has not previously been widely planted. The grape type is first selected by a comparison of the weather in the candidate site with the weather where each of the primary grape types has been successfully planted in the past. Then, the success of the candidate grape type is calculated for the weather in the candidate site using the calibrated relationship from the successful site. From the calculations it is possible to determine just how well the candidate site's wines might compare against those from the already successful site. This should provide some evidence on the commercial viability of the candidate site for the plantation of wine grapes.

The example application is made to the area of Znojmo in the Moravian province of the Czech Republic. Like many of the other former Soviet bloc countries, the historically fine wine producing area of Moravia is in the middle of returning to the production of wines for a market economy. The application is designed to determine just how well we might expect Moravian red wines to compete in a broader market place and how they might be expected to fare against wines produced in well established vineyards elsewhere.

\section{Wine Quality and the Weather}

Table 1a provides a tabulation of several studies of how average wine quality has varied from year to year with the weather that produced the grapes in each vintage. All are studies of red grape wines with the exception of the studies in the Czech Republic, which are based on the Riesling varietal.

\footnotetext{
${ }^{2}$ A precursor to much of this work is Gladstone's (1992) remarkable analysis of Australian vineyard sites. Gladstone details the characteristics that ameliorate weather in many Australian plantation areas and recommends appropriate grape varietals for each. His recommendations have been very successful, especially in Western Australia. See also Haeger and Storchmann (2006).
} 
Table $1 \mathrm{~A}$

Determinants of Average Wine Vintage Quality by Grape Growing Area

\begin{tabular}{|c|c|c|c|c|c|c|c|c|}
\hline Coefficients & $\begin{array}{l}\text { France } \\
\text { Bordeaux }\end{array}$ & $\begin{array}{c}\text { France } \\
\text { Burgundy }\end{array}$ & $\begin{array}{c}\text { Australia } \\
\text { Barossa }\end{array}$ & $\begin{array}{c}\text { France } \\
\text { No. Rhone }\end{array}$ & $\begin{array}{c}\text { France } \\
\text { No. Rhone }\end{array}$ & $\begin{array}{c}\text { France } \\
\text { So. Rhone }\end{array}$ & $\begin{array}{c}\text { France } \\
\text { So. Rhone }\end{array}$ & $\begin{array}{c}\text { Italy } \\
\text { Barolo }\end{array}$ \\
\hline Average Temperature (A) & $\begin{array}{l}0.616 \\
(6.46)\end{array}$ & $\begin{array}{l}0.188 \\
(1.92)\end{array}$ & $\begin{array}{c}6.59 \\
(2.75)\end{array}$ & $\begin{array}{l}0.417 \\
(2.07)\end{array}$ & 0.392 & $\begin{array}{l}0.715 \\
(1.32)\end{array}$ & $\begin{array}{l}0.893 \\
(1.35)\end{array}$ & $\begin{array}{l}0.592 \\
(2.09)\end{array}$ \\
\hline Avg Temp. sq. $\left(\mathrm{A}^{2}\right)$ & - & - & $\begin{array}{c}-0.173 \\
(2.69)\end{array}$ & - & - & - & - & - \\
\hline Harvest Rain $(\mathrm{H})$ & $\begin{array}{c}-0.00386 \\
(4.76)\end{array}$ & $\begin{array}{c}-0.00582 \\
(3.67)\end{array}$ & $\begin{array}{c}-0.0034 \\
(3.29)\end{array}$ & $\begin{array}{c}-0.00997 \\
(6.68)\end{array}$ & -0.0044 & $\begin{array}{c}-0.0114 \\
(2.71)\end{array}$ & $\begin{array}{c}-0.0119 \\
(2.24)\end{array}$ & $\begin{array}{c}-0.0078 \\
(3.62)\end{array}$ \\
\hline Winter Rain (W) & $\begin{array}{c}0.00117 \\
(2.44)\end{array}$ & $\begin{array}{c}0.00115 \\
(1.61)\end{array}$ & - & $\begin{array}{c}0.00414 \\
(2.24)\end{array}$ & 0.00225 & $\begin{array}{c}0.00347 \\
(1.91)\end{array}$ & $\begin{array}{c}0.0030 \\
(1.32)\end{array}$ & $\begin{array}{c}-0.000 \\
(0.01)\end{array}$ \\
\hline Dependent Variable & $\begin{array}{c}\text { Ln of Price } \\
\text { Index }\end{array}$ & $\begin{array}{c}\text { Ln of Price } \\
\text { Index }\end{array}$ & $\begin{array}{c}\text { Ln of Price } \\
\text { Index }\end{array}$ & $\begin{array}{c}\text { Subjective } \\
\text { Quality }\end{array}$ & $\begin{array}{c}\text { Subjective } \\
\text { Quality }\end{array}$ & $\begin{array}{c}\text { Subjective } \\
\text { Quality }\end{array}$ & $\begin{array}{c}\text { Subjective } \\
\text { Quality }\end{array}$ & $\begin{array}{c}\text { Subjective } \\
\text { Quality }\end{array}$ \\
\hline Other Variables & $\mathrm{AV}^{*}$ & $\mathrm{AV}^{*}$ & $\mathrm{AV} / \mathrm{Temp}^{* *}$ & - & - & - & - & - \\
\hline Method of Estimation & OLS & OLS & OLS & OLS & Ordered Probit & OLS & Ordered Probit & OLS \\
\hline $\mathrm{R}^{2}(\mathrm{NOBS})$ & $\begin{array}{l}0.83 \\
(27)\end{array}$ & $\begin{array}{l}0.61 \\
(21)\end{array}$ & $\begin{array}{l}0.86 \\
(25)\end{array}$ & $\begin{array}{l}0.86 \\
(20)\end{array}$ & - & $\begin{array}{l}0.70 \\
(15)\end{array}$ & - & $\begin{array}{l}0.60 \\
(23)\end{array}$ \\
\hline
\end{tabular}

* Age of Vintage; ** Age of Vintage and Average Diurnal Temperature Difference. Mean Temperature is measured in Centigrade Degrees and is taken over the months of April-September; except in Australia where it is October-March, since Australian vintages are harvested in March. (That is, it is the sum of the monthly mean temperatures divided by six.) Harvest rain is measured in millimeters and is the simple sum for August and September; except in Australia where it is the sum for January and February. 
Table $1 B$

Determinants of Average Wine Vintage Quality

by Grape Growing Area

\begin{tabular}{|c|c|c|c|c|c|c|c|}
\hline Coefficients & $\begin{array}{l}\text { Italy } \\
\text { Barolo }\end{array}$ & $\begin{array}{c}\text { Italy } \\
\text { Valpolicella }\end{array}$ & $\begin{array}{c}\text { Italy } \\
\text { Valpolicella }\end{array}$ & $\begin{array}{c}\text { Italy } \\
\text { Amarone }\end{array}$ & $\begin{array}{c}\text { Italy } \\
\text { Amarone }\end{array}$ & $\begin{array}{c}\text { Czech Rep./ } \\
\text { Znojmo }\end{array}$ & $\begin{array}{c}\text { Czech Rep.I } \\
\text { Znojmo }\end{array}$ \\
\hline Average Temperature (A) & $\begin{array}{c}.959 \\
(2.06)\end{array}$ & $\begin{array}{c}3.88 \\
(3.41)\end{array}$ & $\begin{array}{c}.723 \\
(3.09)\end{array}$ & $\begin{array}{c}5.77 \\
(3.97)\end{array}$ & $\begin{array}{c}.888 \\
(3.60)\end{array}$ & $\begin{array}{l}1.407 \\
(4.47)\end{array}$ & $\begin{array}{l}2.127 \\
(3.29)\end{array}$ \\
\hline Avg Temp. sq. $\left(\mathrm{A}^{2}\right)$ & - & - & - & - & - & - & - \\
\hline Harvest Rain (H) & $\begin{array}{c}-.0128 \\
(3.06)\end{array}$ & $\begin{array}{c}-.0446 \\
(2.25)\end{array}$ & $\begin{array}{c}-.00746 \\
(2.23)\end{array}$ & $\begin{array}{c}-.0035 \\
(.123)\end{array}$ & $\begin{array}{c}-.0026 \\
(.76)\end{array}$ & $\begin{array}{c}-.0197 \\
(2.06)\end{array}$ & $\begin{array}{c}-.0306 \\
(2.06)\end{array}$ \\
\hline Winter Rain (W) & $\begin{array}{l}.000 \\
(.26)\end{array}$ & $\begin{array}{l}.0297 \\
(1.72)\end{array}$ & $\begin{array}{l}.00598 \\
(2.13)\end{array}$ & $\begin{array}{l}.0232 \\
(1.02)\end{array}$ & $\begin{array}{l}.0035 \\
(1.32)\end{array}$ & $\begin{array}{c}-.0021 \\
(.191)\end{array}$ & $\begin{array}{c}-.0034 \\
(.263)\end{array}$ \\
\hline $\begin{array}{c}\text { Dependent } \\
\text { Variable }\end{array}$ & $\begin{array}{l}\text { Subjective } \\
\text { Quality }\end{array}$ & $\begin{array}{c}\text { Subjective } \\
\text { Quality }\end{array}$ & $\begin{array}{l}\text { Subjective } \\
\text { Quality }\end{array}$ & $\begin{array}{c}\text { Subjective } \\
\text { Quality }\end{array}$ & $\begin{array}{c}\text { Subjective } \\
\text { Quality }\end{array}$ & $\begin{array}{c}\text { Subjective } \\
\text { Quality }\end{array}$ & $\begin{array}{l}\text { Subjective } \\
\text { Quality }\end{array}$ \\
\hline $\begin{array}{l}\text { Other } \\
\text { Variables }\end{array}$ & - & - & - & - & - & - & - \\
\hline Method of Estimation & $\begin{array}{l}\text { Ordered } \\
\text { Probit }\end{array}$ & OLS & $\begin{array}{c}\text { Ordered } \\
\text { Probit }\end{array}$ & OLS & $\begin{array}{c}\text { Ordered } \\
\text { Probit }\end{array}$ & OLS & $\begin{array}{c}\text { Ordered } \\
\text { Probit }\end{array}$ \\
\hline $\mathrm{R}^{2}$ (NOBS) & - & $.529(20)$ & - & $.601(20)$ & - & $.77(13)$ & - \\
\hline
\end{tabular}

Mean Temperature is measured in Centigrade Degrees and is taken over the months of April-September; except in Australia where it is October-March, since Australian vintages are harvested in March. (That is, it is the sum of the monthly mean temperatures divided by six.) Harvest rain is measured in millimeters and is the simple sum for August and September; except in Australia where it is the sum for January and February. 
Table $1 C$

Determinants of Average Wine Vintage Quality

by Grape Growing Area

\begin{tabular}{lccc}
\hline \multicolumn{1}{c}{ Coefficients } & $\begin{array}{c}\text { Greece (No.) } \\
\text { Naoussa }\end{array}$ & $\begin{array}{c}\text { Greece (No.) } \\
\text { Naoussa }\end{array}$ & $\begin{array}{c}\text { Greece: } \\
\text { Naoussa, Thira, Nemea, Iraklion }\end{array}$ \\
\hline Average Temperature (A) & .811 & 8.47 & 12.85 \\
& $(2.24)$ & $(.510)$ & $(1.31)$ \\
Avg Temp. sq. (A $\left.{ }^{2}\right)$ & - & -.168 & -.267 \\
& & $(.45)$ & $(1.22)$ \\
Harvest Rain (H) & -.00374 & - & - \\
Winter Rain (W) & $(.653)$ & - & - \\
& -.0019 & & Subjective Quality \\
Dependent Variable & $(1.56)$ & Subjective Quality & - \\
Other Variables & - & - & OLS \\
Method of Estimation & OLS & OLS & $.43(32)$ \\
$\mathrm{R}^{2}$ (NOBS) & $.57(13)$ & $.43(13)$ & \\
\hline
\end{tabular}

Mean Temperature is measured in Centigrade Degrees and is taken over the months of April-September; except in Australia where it is October-March, since Australian vintages are harvested in March. (That is, it is the sum of the monthly mean temperatures divided by six.) Harvest rain is measured in millimeters and is the simple sum for August and September; except in Australia where it is the sum for January and February.

\section{A. Basic Determinants of Vintage Quality}

The basic model underlying most of these analyses of grape quality includes three key variables: (a) the average temperature over the grape growing season (April through September), (b) the rainfall near the date of harvest (August and September), and (c) the rainfall during the previous winter. There is considerable anecdotal evidence from horticultural research that these are critical variables for the determination of fruit quality. See especially Winkler (1962).

Summarized briefly, the reasoning is that grapes are typically (but not always) planted in places where they ripen toward the end of the normal growing season (which halts when the temperature falls below about 55 degrees Fahrenheit). As a result, the better vintages tend to correspond to the growing seasons where grapes fully ripen and this typically occurs when the growing season is warmer than normal for a given area. Likewise, rainfall near the harvest time results in grapes that are diluted and contain a lower concentration of fruit extracts. Finally, since the vines are typically stressed at the end of the growing season, they will best support this stress if the previous part of the year has witnessed plenty of rainfall.

There is also considerable anecdotal evidence from vineyard site selection and winemaking techniques that these three factors are crucial to grape quality. First, in most areas of Europe vineyard site selection is based on the goal of reducing the problems produced by inadequate warmth and excessive rainfall at the end of the growing season. The best vineyard sites tend to be on slopes with southern or southeastern exposures which maximize the warmth of the sun (see Ashenfelter 
and Storchmann, 2010a, for evidence of this relation from Germany's Mosel valley). Likewise, the best vineyard sites are exemplars of natural drainage, minimizing the damage from late season rainfall. In some cases, canopies have been erected over entire vineyards to ward off harvest rains.

Second, many winemaker techniques are designed to overcome the deficiencies that result when grapes are either unripe or diluted. Sugar is added to compensate for unripe fruit, and various techniques have been designed to concentrate the grape's juice. (It is unclear how successful the latter techniques, which range from boiling the fermenting grape juice to cryoextraction and reverse osmosis, have been.)

The most straightforward studies measure wine quality by the price that the average wine from a vintage fetches in organized auctions. In practice, this measure of quality is only available for the wines of Bordeaux and Burgundy. Studies by Ashenfelter (2010), Ashenfelter, Ashmore, and Lalonde (1995), Ginsburgh, Monzak, and Monzak (2013), Jones and Storchmann (2001), and deVittori and Ginsburgh (1996) have documented the role of the basic factors in the determination of Bordeaux prices. Ashenfelter and Storchmann (2016a, 2016b) provide an extensive literature review that also includes other wine growing regions. The analysis in the first column of Table 1 reports the so-called "Bordeaux equation," a cross-section regression of the vintage price on the weather variables indicated (and, although unreported, the age of the vintage, to account for the real rate of interest.)

This basic regression has also been fitted to data on Burgundy wines, and the results have been discussed (although the regression never reported) in various issues of Liquid Assets (see Ashenfelter (ed.), various issues). Although of lower explanatory power, this "Burgundy equation" performs reasonably well. It is very interesting to note how the coefficients differ between the regressions reported in columns 1 arid 2. Although the effect of the winter rain is similar, the harvest rain has a more important effect in Burgundy than Bordeaux, while the temperature during the growing season has a far more important effect in Bordeaux than in Burgundy.

This is an important result for the hedonic analysis of vineyard sites since it almost certainly reflects the effect of the use of cabernet and merlot grapes in Bordeaux versus the use of the pinot noir grape in Burgundy. The regressions imply that areas like Burgundy, where it is hard to ripen grapes, may be successful with pinot noir so long as harvest rainfall is not excessive. Likewise, warmer areas may be satisfactory for cabernet even if rainfall at harvest time is sometimes a serious problem.

\section{B. Analyses with Subjective Vintage Quality Measures}

The other columns of the table report a series of additional analyses from different areas. Unfortunately, with the exception of Australia, there are very few organized 
auction markets for the relevant wines. ${ }^{3}$ The result is that many researchers have resorted to the use of subjective quality measures.

In principle, there is nothing wrong with the use of these subjective measures of quality except that they make it difficult to compare results from different areas. The basic problem is that the subjective measures have no common scale. Despite this, it is possible to determine how well a different area would fare using the same scale on which the subjective scale is based. It would also be useful, however, to convert estimates based on subjective scales to be comparable to those based on price scales and to other subjective scales.

It is possible to show that, under some strong assumptions, estimates using different subjective measures may be compared. In particular, assume that the subjective quality measure is geared to estimate the logarithm of the price apart from a linear scale transformation and a random measurement error. This implies that ordinal predictions of quality will be the same whether based on a subjective measure of quality or on observed prices. The distribution function assumed for this measurement error leads to a functional form for estimation of the relationship between the subjective quality measure and the weather variables. Assuming a uniform distribution for the measurement error leads to a simple regression estimator, while assuming normality leads to an ordered probit estimator. Examples of both of these are provided in Table 1.

Summarizing briefly, grapes grown in the Rhone Valley in France seem to behave in a way similar to Burgundy and Bordeaux. The syrah is the grape grown in the northern Rhone and the regression for data from this area seem fully consistent with the results from other areas of France. Other areas with considerable similarity include the Barolo area of Italy, and the Moravian area of the Czech Republic.

\section{Other Variables}

Several important lessons are emerging from these studies. First, it is quite feasible to produce studies of the effect of the weather on wine quality even when reliable price data do not exist. Second, and most important, not all these analyses indicate equal importance for the same climatic variables.

\section{(1) Nonlinearity in Temperature}

First, several of these studies are indicating that in warmer areas the growing season may sometimes be warmer than is optimal. An early analysis by Byron and Ashenfelter (1995), displayed in Table 2 indicates the Syrah (Shiraz) grapes of

\footnotetext{
${ }^{3}$ However, Ashenfelter and Storchmann (2010b) show that referring to auction prices only may lead to biased results when estimating weather's impact on a wine growing region. Drawing on German wine prices they find that only wines in higher price brackets are sold at auction and that these wines are more weather sensitive than low-price wines.
} 
Table 2

Characteristics of the Weather by Wine Growing Regions AREA

\begin{tabular}{|c|c|c|c|c|c|c|c|c|c|}
\hline Coefficients & Bordeaux & Burgundy & Barossa & No. Rhone & So. Rhone & Barolo & Valpolicella & $\begin{array}{l}\text { Znojmo } \\
(C Z)\end{array}$ & $\begin{array}{l}\text { Naoussa } \\
\text { Greece }\end{array}$ \\
\hline $\begin{array}{l}\text { Mean Temperature Over } \\
\text { the Growing Season (A) }\end{array}$ & 16.7 & 15.8 & 18.7 & 16.8 & 19.3 & 17.5 & 21.8 & 14.9 & 21.99 \\
\hline St. Deviation of A & .82 & .71 & .63 & .89 & .75 & .48 & 1.61 & .71 & .65 \\
\hline (Min, Max) & $(15,18.7)$ & $(14.5,17.2)$ & $(17.4,19.9)$ & $(15,19.2)$ & $(17.8,20.7)$ & $(16.7,18.2)$ & $(18.6,24)$ & $(13.4,16.6)$ & $(20.9,23)$. \\
\hline Mean Harvest Rain $(\mathrm{H})$ & 145 & 133 & 38 & 171 & 126 & 128 & 171 & 91 & 52 \\
\hline St. Deviation of $\mathrm{H}$ & 75 & 62 & 33 & 73 & 72 & 70 & 91 & 33 & 39 \\
\hline (Min, Max) & $(38,342)$ & $(48,325)$ & $(.5,138)$ & $(18,362)$ & $(26,276)$ & $(31,256)$ & $(29,324)$ & $(34,156)$ & $(3,124)$ \\
\hline Mean Winter Rain & 599 & 402 & 339 & 378 & 446 & 325 & 372 & 152 & 390 \\
\hline St. Deviation & 130 & 95 & 95 & 103 & 153 & 113 & 107 & 47 & 160 \\
\hline (Min, Max) & $(376,845)$ & $(256,582)$ & $(137,541)$ & $(212,783)$ & $(214,785)$ & $(187,536)$ & $(177,581)$ & $(71,265)$ & $(133,621)$ \\
\hline (Quality Measure) & 3.16 & 4.33 & 4.65 & 3.3 & 3 & 2.5 & 66.5 & 3.8 & 3.2 \\
\hline Mean St. Deviation & .63 & .45 & .38 & 1.3 & 1.6 & 1.2 & 10.4 & 1.6 & 1.0 \\
\hline (Min, Max) & $(2.3,4.6)$ & $(3.37,5.14)$ & $(4.19,5.93)$ & $(1,5)$ & $(1,5)$ & $(1,4)$ & $(50,90)$ & $(2,7)$ & $(1.3,4.6)$ \\
\hline
\end{tabular}

Mean Temperature is measured in Centigrade Degrees and is taken over the months of April-September; except in Australia where it is October-March, since Australian vintages are harvested in March. (That is, it is the sum of the monthly mean temperatures divided by six.). Harvest rain is measured in millimeters and is the simple sum for August and September; except in Australia where it is the sum for January and February. 
Australia are often planted in areas far warmer than those of the northern Rhone. The third column of Table 1 indicates that, indeed, the temperature over the growing season is sometimes too warm. A quadratic in temperature adds significantly to the explanatory power of the regression equation for Australia. A simple calculation indicates that the optimal temperature is near the mean temperature in the Australian area studied. The best Australia vintages come from the "typical" growing seasons, neither the warmest nor the coolest. It is tempting to think that early grape growers may have known this, and that is why they focused on the shiraz grape for their plantations, but I am not aware that there is any evidence to support this hypothesis.

Another example is provided by the data for Greece, also a very warm grape growing area. A scatter diagram indicating the relation between a vintage quality index and average temperature for the area of Naoussa in northern Greece is contained in Figure 1. (The plotting symbol indicates the vintage year.) Figure 1 gives the strong impression that growing seasons with temperatures far above normal provide only a small increase in the quality of the vintage. This is also confirmed by the regression results for Greece in Table 1, which indicate that a concave (quadratic) relation between the quality measure and temperature provides a better fit to the data. The calculated optimum temperature is around 23 degrees Centigrade, which is warmer than all but a few of the growing seasons in the data available. As Table 2 indicates, Greece generally has the warmest growing seasons of any of the vineyard areas studied to date, and the grape varieties planted there tend, as a result, to be the most difficult to ripen in cooler climates.

\section{(2) Other Variables}

Several other variables of some importance for vintage quality have now also been identified. Gladstones (1992) has argued, and Byron and Ashenfelter (1995) in their study of Australian wine have found, that diurnal temperature fluctuations may be harmful for wine quality. This is a potentially important finding for two reasons. First, in areas that are very warm some grape growers have been tempted to find vineyard sites that have lower mean growing season temperatures by turning to sites that have greater diurnal temperature fluctuations. (That is, there has been a search for sites that have similar daytime temperatures, but lower night time temperatures.) It is quite possible that these lower temperature sites actually provide no improvement in grape quality, or at least that they provide far less improvement than is expected, because of the accompanying increase in the diurnal temperature difference. Second, this finding provides an explanation for why some site-specific characteristics (such as evening fog, which increases humidity and prevents night time temperature reductions) may be helpful for grape quality.

One of the most fascinating additional variables analyzed is the humidity during the grape growing season. There is evidence that the quality of Amarone, which is made by dehydrating the fruit following the growing season, is influenced by the 
Figure 1

Wine Quality in Naoussa, Greece vs. Average Growing Season Temperature 1983-1994

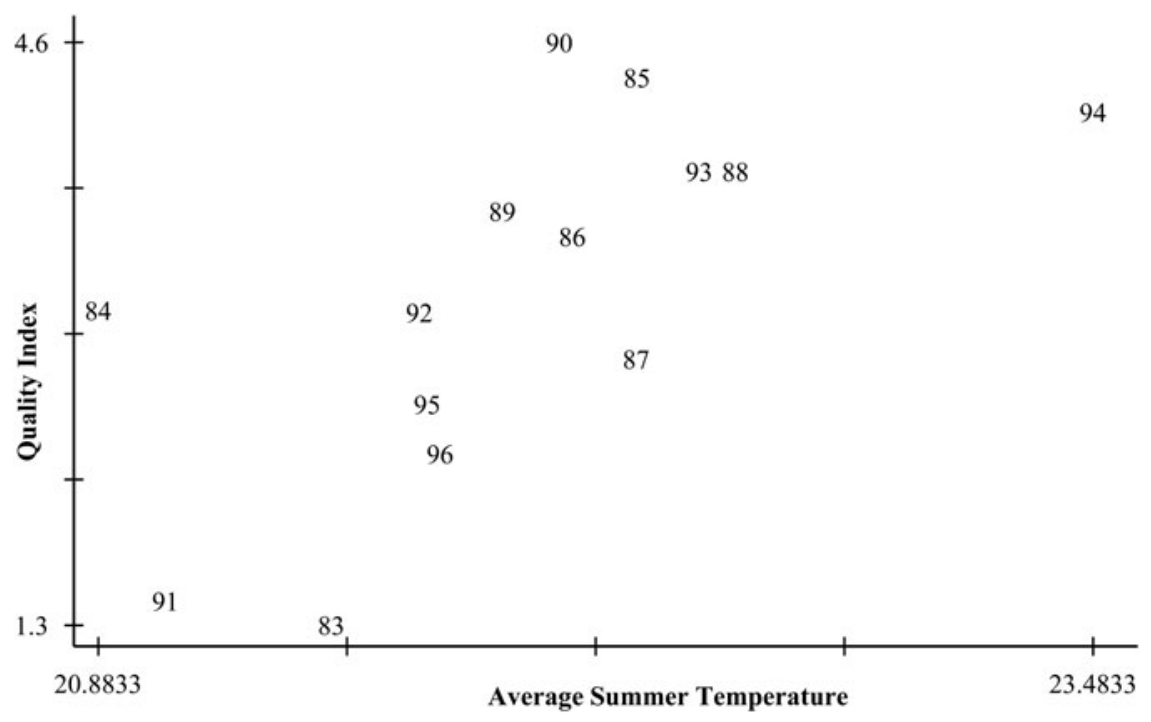

humidity during the fall. When the fall is less humid, the drying process is more successful and the resulting wines are of higher quality.

\section{The Hedonic Selection of Vineyard Sites: An Example}

Table 2 contains detailed data on the characteristics during the growing season in a number of vineyard areas. Some of these, like Bordeaux, Burgundy, and the northern Rhone set the world standard for the wines made from cabernet sauvignon, pinot noir, and syrah (shiraz). It seems reasonable, therefore, to assume that a "good" growing season in one of these areas provides a benchmark for the climate that is likely to be successful for wine grape growing.

To see how this approach works, consider the area of Znojmo in Moravia. It is apparent from Table 2 that Znojmo has a very low temperature compared to most of the successful red wine grape growing areas. Only Burgundy has a temperature that is nearly as low. This immediately suggests that, if high quality wine grapes are to be grown in Moravia, it is much more likely that these grapes will be of the pinot noir variety than of the cabernet sauvignon, Syrah, or a southern Rhone variety.

An extremely interesting feature of the Moravian climate is the very low rainfall normally received during the harvest period. Indeed, in this regard Znojmo is 
Figure 2

Wine Quality in Moravia vs. Predicted Quality

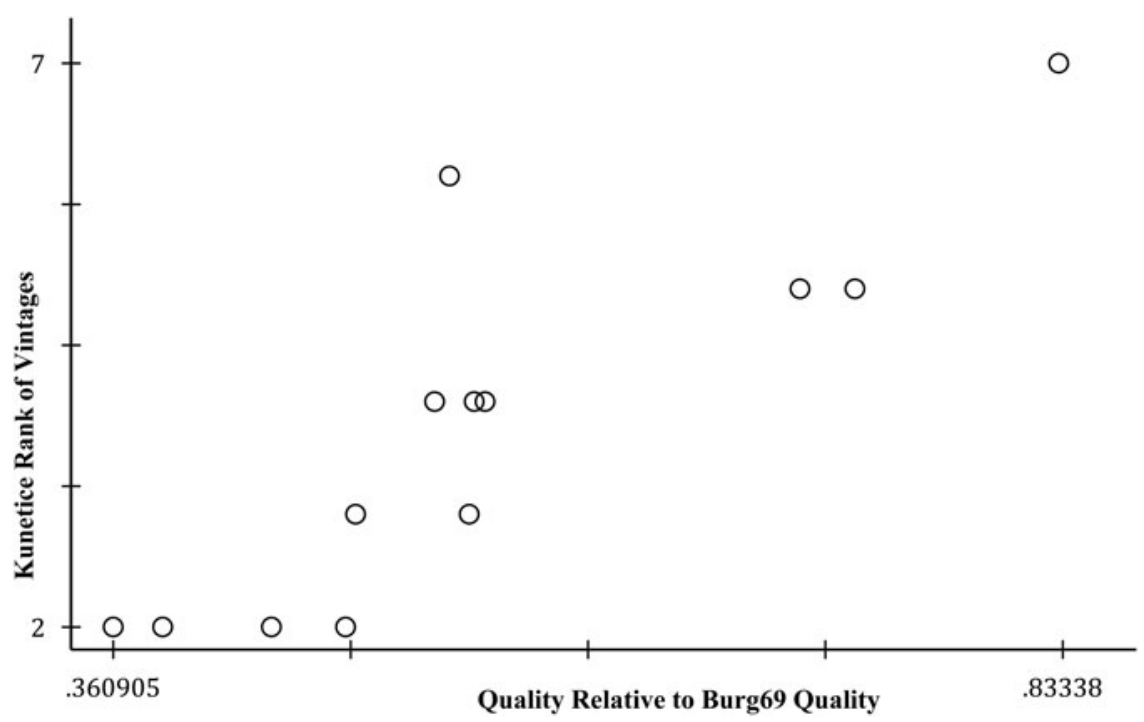

more like Australia than Burgundy. Since rainfall at the harvest has a very large effect on grape quality in Burgundy, this suggests that lower harvest rainfall may compensate for Znojmo's low temperatures in pinot noir is planted.

How well would a Znojmo pinot noir vintage be likely to be? This is actually a straightforward calculation to make and requires only substitution of the data from Znojmo into the Burgundy regression equation in Table 1. The basic results are summarized in Figure 2. First, note that the horizontal axis in Table 2 indicates what the quality of each vintage would be in Znojmo if the same grape, micro-site, recipe, and winemaker skill were employed in Znojmo as is employed in Burgundy. For this purpose the vintage of 1969, widely considered outstanding in Burgundy, has been used as a benchmark. Thus the x-axis indicates the proportion of the quality of a top Burgundy vintage that the Moravians could have achieved. Briefly, summarized, the highest quality vintage in Znojmo would have been about $83 \%$ of the quality of a top Burgundy vintage. On the other hand, the worst Znojmo vintage would have been twice the quality of the worst Burgundian vintage in the period from 1979 to 1992. On average, the typical Znojmo vintage would have been about $75 \%$ of the quality of the typical Burgundian vintage. This suggests that there is considerable potential for producing high quality pinot noir wines in the Czech Republic. ${ }^{4}$

\footnotetext{
${ }^{4}$ Indeed, since these calculations were made, several Moravian wineries have begun producing pinot noir. See, for example, http://stapleton-springer.cz/en-eshop.php
} 
Finally, the vertical y-axis in Figure 2 displays a subjective measure of wine quality that was collected from a group of wine makers and grape growers in the Moravian region for the grapes then growing there (mainly Muller-Thurgau and Riesling). The ratings were solicited before the growers were informed of the predictions based on the weather that are contained on the horizontal $\mathrm{x}$-axis. It is apparent that this quality measure is highly correlated with the predictions.

\section{References}

Ashenfelter, O. (2010). Predicting the prices and quality of Bordeaux wines. Journal of Wine Economics, 5(1), 40-52.

Ashenfelter, O. (ed.) (various issues). Liquid Assets: The International Guide to Fine Wines. Princeton, NJ.

Ashenfelter, O., Ashmore, D., and Lalonde, R. (1995). Bordeaux wine, vintage quality and the weather. Chance, 8(4), 7-14.

Ashenfelter, O., and Storchmann, K. (2010a). Using a hedonic model of solar radiation to assess the economic effect of climate change: the case of Mosel valley vineyards. Review of Economics and Statistics, 92(2), 333-349.

Ashenfelter, O., and Storchmann, K. (2010b). Measuring the economic effect of global warming on viticulture using auction, retail and wholesale prices. Review of Industrial Organization, 37, 51-64.

Ashenfelter, O., and Storchmann, K. (2016a). The economics and wine, weather, and climate change. Review of Environmental Economics and Policy, 10(1), 25-46.

Ashenfelter, O., and Storchmann, K. (2016b). Wine and climate change: A review of the economic consequences. Journal of Wine Economics, 11(1), 105-138.

Byron, R.P., and Ashenfelter, O. (1995). Predicting the quality of the unborn Grange. The Economic Record, 71(212), 40-53.

Di Vittorio, A., and Ginsburgh, V. (1996). Pricing red wines of Medoc vintages from 1949 to 1989 at Christie's auctions. Journal de la Société Statistique de Paris, 137, 19-49.

Gladstone, J. (1992). Viticulture and Environment. Winetitles: Adelaide.

Ginsburgh, V., Monzak, M., and Monzak, A. (2013). Red wines of Médoc: What is wine tasting worth? Journal of Wine Economics, 8(2), 159-188.

Haeger, J.W., and Storchmann, K. (2006). Prices of American Pinot Noir wines: climate, craftsmanship, critics. Agricultural Economics, 35(1), 67-78.

Jones, G.V., and Storchmann, K. (2001). Wine market prices and investment under uncertainty: an econometric model for Bordeaux crus classés. Agricultural Economics, 26(2), 115-133.

Winkler, A.J. (1962). General Viticulture. $1^{\text {st }}$ ed., University of California Press: Berkeley and Los Angeles. 